\title{
Urticaria-Angio Edema: Profile of Patients in the Emergency Department and Factors Affecting Revisits
}

\section{Ürtiker ve Anjiyoödem: Acil Servis Hasta Profili ve Tekrarlayan Başvurular}

\author{
Yeliz BERK, ${ }^{1}$ Oktay ERAY, ${ }^{2}$ Özlem YiĞit, ${ }^{2}$ Neslihan SAYRAÇ, ${ }^{2}$ Erkan ALPSOY ${ }^{3}$ \\ 'Adana Numune Hospital, Adana; \\ ${ }^{2}$ Department of Emergency Medicine, Akdeniz University Faculty of Medicine, Antalya; \\ ${ }^{3}$ Department of Dermatology, Akdeniz University Faculty of Medicine, Antalya, Turkey
}

\begin{abstract}
SUMMARY
\section{Objectives}

The precise definition of the acute urticaria patients presenting to emergency department will improve the clinical approach to the urticaria patient. The aim of this study is to define the demographic features of urticaria patients visiting the emergency department and to find the factors that affect emergency department revisits due to urticaria symptoms.
\end{abstract}

\section{Methods}

This was a retrospective case control study. Patients aged 16 and older were enrolled to the study. The number of revisits for the same complaints in the five days following the first visit was determined and the factors affecting the number of recurrent visits was searched.

\section{Results}

The mean age of 3813 urticaria patients was $40.2 \pm 15.8,2304$ of whom were female. 2940 were triaged as non-urgent and 3787 were discharged from the emergency department. The 78 patients with recurrent visits were identified and there was no significant difference between the sex, urticaria or allergy history in the past, receiving $\mathrm{H} 1$ and $\mathrm{H} 2$ receptor blockers together or receiving two different $\mathrm{H} 1$ receptor blockers, the season of the year, comorbid diseases, or medicines for chronic illness between patients who visited the emergency department once and those who visited the emergency department repeatedly. The presence of a possible cause for the urticaria symptoms and chronic urticaria diagnosis were found to be more common in the revisit group.

\section{Conclusions}

This study has pointed out that scores of urticaria patients are entering emergency departments and these patients may have life-threatening problems. This information can be used to modify emergency clinic curriculum and can contribute to the standardization of urticaria management and follow up. Future prospective studies may be conducted for urticaria management in light of our results.

Key words: Emergency department; urticaria, treatment, outcome.

\section{ÖZET}

\section{Amaç}

Acil servise başvuran akut ürtiker hastalarının tam olarak tanımlanması, klinik yaklaşımı geliştirecektir. Çalışmadaki amacımız acil servise başvuran ürtiker hastalarının demografik özelliklerini ve ürtiker semptomlarına bağlı tekrarlayan acil servis başvurularını etkileyebilecek faktörleri tanımlamaktır.

\section{Gereç ve Yöntem}

Bu çalışma geriye dönük bir vaka kontrol çalışması olarak yapıldı. On altı yaş ve üzerindeki hastalar çalışmamıza alındı. Beş gün içinde aynı şikâyetlerle acil servise tekrar başvuran hastalar belirlendi ve hastaların tekrarlayan başvurularını etkileyebilecek faktörler araştırıldı.

\section{Bulgular}

Çalışmamıza alınan 3813 ürtiker hastasının, ortalama yaşı 40.2 \pm 15.8 , 2304'ü (\%60.4) kadın, 2940'ı (\%77.1) az acil triyaj kategorisindeydi ve hastaların 3787'si (\%98.8) acil servisten taburcu edilmişti. Acil servise tekrarlayan başvurularda bulunan 78 hasta kontrol grubuyla karşılaştırıldığında, cinsiyet, alerji ve/veya ürtiker öyküsü, eşlik eden hastalık veya bu nedenle kullanılan kronik ilaç varlığı, başvurdukları mevsim, taburculuk tedavilerinde $\mathrm{H} 1$ reseptör antagonistine $\mathrm{H} 2$ veya ikinci bir $\mathrm{H} 1$ reseptör antagonistinin eklenmesi arasında fark bulunmadı. Ürtikere yol açan olası bir neden saptanması ve kronik ürtikere dönüşüm tekrarlayan başvuru grubunda daha sık görülmekteydi.

\section{Sonuç}

Bu çalışma acil servise çok sayıda ürtiker hastasının acil servise başvurduğunu göstermiştir ve bu hastaların hayatı tehdit eden problemleri olabilir. Bu bilgi acil sağlık hizmeti veren hekimlerin eğitim müfredatlarının düzenlenmesi ve ürtiker yönetimi ve takibinin standart hale getirilmesi için kullanılabilir. Çalışmamızın sonuçlarının ışı̆ıında gelecekte ileriye dönük çalışmalar planlanabilir.

Anahtar sözcükler: Acil servis; ürtiker, tedavi, prognoz. 


\section{Introduction}

Urticaria represents the most frequently observed skin disorder (35\%) presenting in an emergency department. ${ }^{[1]}$ Acute urticaria or acute exacerbations of chronic urticaria constitute the emergency department visits. The concomitant factors for urticaria can change the management of urticaria in emergency departments. The recurrence of the urticaria symptoms despite of emergency treatment is the cause of emergency department revisits. Acute urticaria may progress to life-threatening angioedema and/or anaphylactic shock in a very short period of time and basic aim of an emergency physician is to realize the presence of anaphylaxis or to prevent its occurrence. Concurrently with anaphylaxis, emergency physicians should treat the urticaria symptoms and give information to the patient about the disease.

The etiology, pathophysiology and treatment of urticaria still remain numerous discrepancies and knife edge. The recurrence of symptoms in spite of treatment and avoidance of new attacks have not been demystified. ${ }^{[2]}$ Considering the emergency department visits, the profile of acute urticaria patients in our population has not been described with adequate patient number. Finding out the demographics and distributions of acute urticaria patients in emergency departments can affect the patient care and department preparations.

Acute urticaria patients have been thought to seek treatment generally from the dermatology or allergy-immunology clinics. However these clinics are rare in some parts of the country and the patients usually prefer to visit the dermatology or allergy-immunology clinics for further evaluation after they are treated in an emergency department for acute attacks. In fact, urticaria is the most common cutaneous disease treated in the emergency departments and defining the patient population can give useful information about acute urticaria. This information can be used for modifying emergency clinics curriculum, as well as the public health statistics and can contribute to the standardization of the urticaria management and follow up.

The aim of this study is to define the demographic features of urticaria patients visiting the emergency department and to find the factors which can affect the emergency department revisits due to urticaria symptoms.

\section{Materials and Methods}

Prior to beginning of the study, the ethic approval was received from Akdeniz University Faculty of Medicine local ethical committee. By searching the previous seven years' emergency department hospital records, a special patient subgroup was constituted and a retrospective case control study was developed with this subgroup. For this reason, the study could be assessed in two stages.

At the first stage, all patients aged 16 and older, visiting the emergency department with different complaints between 01 January 2001-30 April 2008 and which were coded as urticaria (L50) according to the to ICD-10 (International Classification of Diseases 10th revision and Clinical Modification) codes in Akdeniz University Emergency Department database were found. The age and gender of the patients, application date, emergency department triage category, and referral type after emergency treatment were enrolled. The application dates were assessed in two different categories as months and seasons. All patients were triaged with triple triage system, used in our emergency department. According to this system, patients with rash and systemic involvement were triaged as 'urgent', patients only having rash triaged as 'non-urgent', and patients with shock or difficulty in breathing triaged as 'emergent'. Referral type after treatment was classified as 'hospitalized' or 'discharged'. All data were recorded to SPSS 16.0 for windows.

At the second stage, patient revisits with same symptoms within the first 5 days after emergency department treatment and discharge, were found in all urticaria records. Limiting the revisit time as the following 5 days was determined with a thought that this period could reflect the patients' dissatisfaction and inadequate treatment. This subgroup was classified as 'revisit group'. The detailed records of 102 patients in revisit group were searched in Akdeniz University Hospital database archives and full records of 78 patients were attained and these patients were enrolled to the study. In the SPSS 16.0 for windows program, 102 'revisit' patients were deleted from the total of 3813 patients and $4 \%$ of remained patients were randomized automatically for the 'control group'. There were 141 patients in the 'control group' and detailed records of 91 patients were found, therefore 91 patients were enrolled to the study. From the detailed records; patients' age, gender, application date, allergy history in the past, comorbid diseases and medicines for chronic illness, the presence of a possible reason for the urticaria symptoms, experienced urticaria and prescribed medications on discharge were recorded. Furthermore, it was also searched if these patients turned to dermatology or allergyimmunology clinics for check examinations and if they were diagnosed as 'chronic urticaria'. All these data were enrolled to SPSS 16.0 for windows too.

Basic descriptive statistics were used to analyze the data collected at the first stage. Chi-square test was used for the distributions, medians, comparisons of the seasons and the categorical evaluations of the parameters of the data collected at the second stage. T-test was used to compare the evaluation values. 


\section{Results}

The results were collected at two stages. At first stage, 3813 patients found from the Akdeniz University Emergency Department database according to the ICD-10 codes were evaluated. Patient flow chart was shown in Fig. 1. From the total of 3813 patients, 1509 (39.6\%) were male and the remained 2304 (60.4\%) were female. According to the triple triage system, 2940 (77.1\%) patients were triaged as 'nonurgent', 821 (21.5\%) patients as 'urgent', and $52(1.4 \%)$ as 'emergent'. The application dates were classified as seasons. December-January-February was categorized as group 1, March-April-May was categorized as group 2, June-JulyAugust was categorized as group 3, and September- October- November was categorized as group 4. There were 889
(23.3\%) patients in group 1, 970 (25.4\%) patients in group 2, 1015 (26.6\%) patients in group 3, and 939 (24.6\%) patients in group 4. While 46 patients (1.2\%) were hospitalized either in dermatology or internal medicine-allergy clinic wards, 3767 patients (98.8\%) were discharged from the emergency department (Table 1). There was not any significant statistical difference between the sex and emergency department referral type $(p=0.951) .102$ patients returned to emergency department with same complaints within the following 5 days after discharge. The revisit ratio was calculated as $2.6 \%$ from total patient number.

The data of the 'revisit group' and 'control group' were analyzed and two groups were compared to search the factors which can affect the emergency department revisits due to

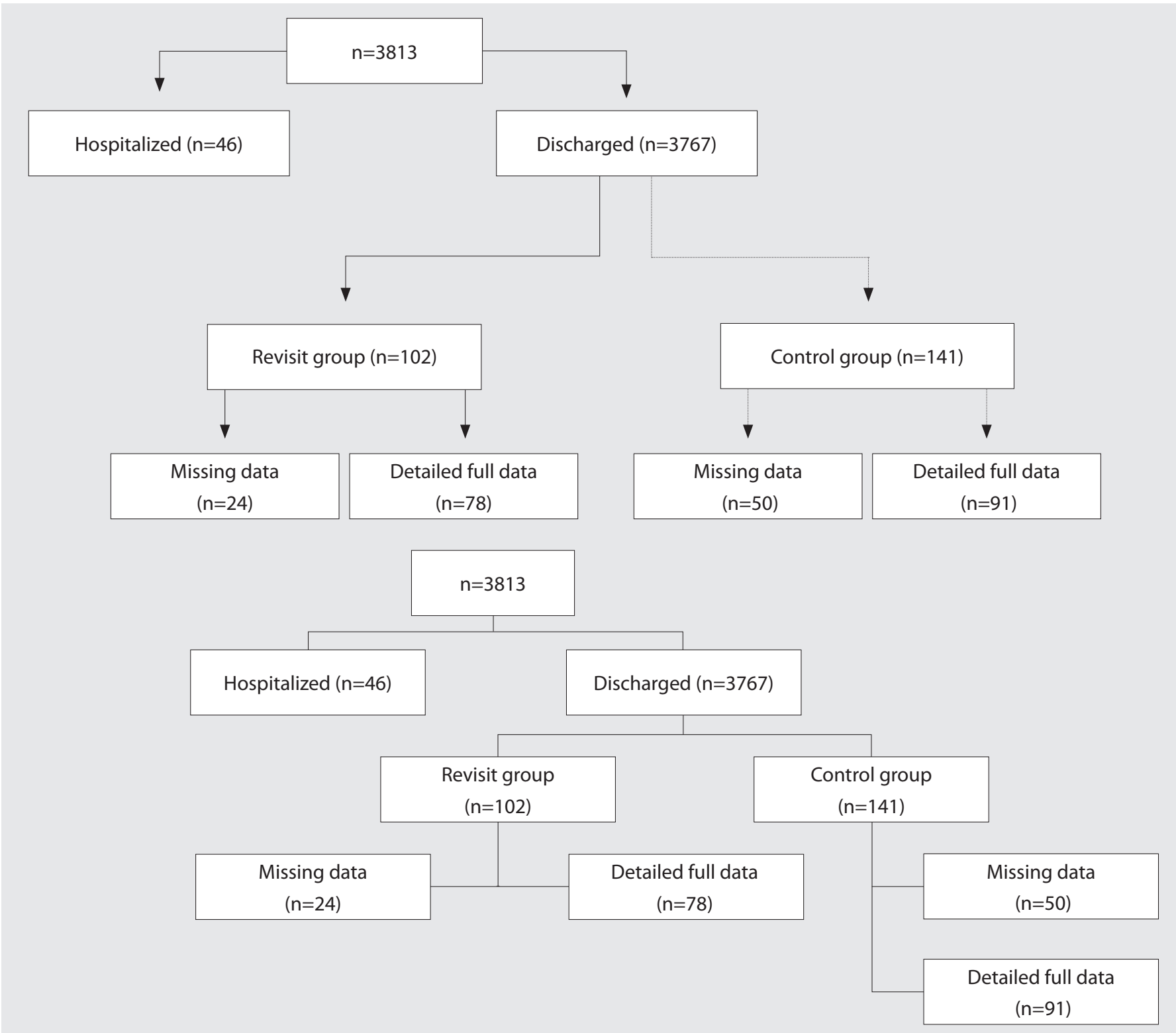

Figure 1. Patient flow chart. 
Table 1. The demographics of the urticaria patients

\begin{tabular}{lcc}
\hline Characteristics & $\begin{array}{c}\text { Patient } \\
\text { number } \\
\text { (n=3813) }\end{array}$ & $\%$ \\
\hline Gender & & \\
Male & 1509 & 39.6 \\
Female & 2304 & 60.4 \\
Triage & & \\
Non-urgent & 2940 & 77.1 \\
Urgent & 821 & 21.5 \\
Emergent & 52 & 1.4 \\
Season* & & \\
1. group & 889 & 23.3 \\
2. group & 970 & 25.4 \\
3. group & 1015 & 26.6 \\
4. group & 939 & 24.6 \\
Emergency department referral type & & \\
Discharged & 3767 & 98.8 \\
Hospitalized & 46 & 1.2 \\
Revisit & & \\
No & 3711 & 98.0 \\
Yes & 102 & 2.6 \\
\hline
\end{tabular}

Season* ${ }^{*}$ December-January-February group 1; March-April-May group 2; June-July-August group 3; September-October-November group 4.

urticaria symptoms. When compared with chi-square test there was not any significant statistical difference between the two groups for gender $(p=0.940)$. The mean age was $40.34 \pm 18.28$ in control group and $42.28 \pm 15.59$ in revisit group. There was not any significant difference between the allergy history in the past $(p=0.826)$, urticaria history $(p=0.323)$, comorbid diseases $(p=0.7)$, medicines for chronic illness ( $p=0.652)$, the season of the year $(p=0.954)$. The presence of a possible cause for the urticaria symptoms $(p<0.001)$ and conversion to chronic urticaria ( $p=0.021$ ) were found to be statistically different in revisit group (Table 2).

According to the patients' anamnesis, 7 patients reported a suspected food and 39 patients reported a suspected drug. All 7 patients reported a suspected food were in revisit group. In the emergency department, all patients were treated with intravenous antihistaminic and steroid therapy and due to the clinical necessity epinephrine was given. All discharged patients were prescribed an $\mathrm{H} 1$ antagonist. Comparing the patients who had $\mathrm{H} 1$ antagonist alone or with a $\mathrm{H} 2$ antagonist revealed no significant differences $(p=0.784)$. There was not any significant difference between the patients who were prescribed a second $\mathrm{H} 1$ antagonist regardless of whether an $\mathrm{H} 2$ antagonist was given or not $(p=0.936)$.

\section{Discussion}

Acute urticaria is the most frequent skin disorder (35\%) presenting in an emergency department. ${ }^{[1]}$ Although the prevalence of urticaria in the population differs in various sources, it has been changing between $15-25 \% \cdot{ }^{[3]}$ During the study period, approximately 300.000 patients entered to the Akdeniz University Emergency Department and the prevalence of acute urticaria in our population was calculated as $1.3 \%$, which was lower than the general population. Since they have learned many things about their illnesses during their previous attacks, many of the urticaria patients may not prefer to go to an emergency department or any other doctor's office. Concurrently with this fact, the patients may also prefer the primary care clinics where they can get care quickly and easily to a university hospital. Since urticaria is a common disease and it is a main topic in the curriculum of medicine faculties, all primary care physicians learn the standard urticaria management before graduation and they

Table 2. Comparisons of the data of the 'revisit group' and 'control group'

\begin{tabular}{|c|c|c|c|c|c|}
\hline \multirow[b]{2}{*}{ Data } & \multicolumn{2}{|c|}{ Revisit group } & \multicolumn{2}{|c|}{ Control group } & \multirow{2}{*}{$\frac{\text { Q-square }}{\text { p }}$} \\
\hline & $\begin{array}{c}\text { Patient } \\
\text { number } \\
(n=78)\end{array}$ & $\%$ & $\begin{array}{c}\text { Patient } \\
\text { number } \\
(\mathbf{n}=91)\end{array}$ & $\%$ & \\
\hline \multicolumn{6}{|l|}{ Gender } \\
\hline Female & 51 & 65.4 & 59 & 64.8 & 0.940 \\
\hline Male & 27 & 34.6 & 32 & 35.2 & \\
\hline \multicolumn{6}{|c|}{ Seasonal distributions } \\
\hline 1. group & 15 & 19.2 & 17 & 18.7 & 0.954 \\
\hline 2. group & 18 & 23.1 & 22 & 24.2 & \\
\hline 3. group & 25 & 32.1 & 26 & 28.6 & \\
\hline 4. group & 20 & 25.6 & 26 & 28.6 & \\
\hline \multicolumn{6}{|c|}{ Allergy history } \\
\hline No & 58 & 74.4 & 69 & 75.8 & 0.826 \\
\hline Yes & 20 & 25.6 & 22 & 24.2 & \\
\hline \multicolumn{6}{|c|}{ Comorbid diseases } \\
\hline No & 44 & 56.4 & 54 & 59.3 & 00.7 \\
\hline Yes & 34 & 43.6 & 37 & 40.7 & \\
\hline \multicolumn{6}{|c|}{ Medicines for chronic illness } \\
\hline No & 55 & 70.5 & 67 & 73.6 & 0.652 \\
\hline Yes & 23 & 29.5 & 24 & 26.4 & \\
\hline \multicolumn{6}{|c|}{ Urticaria history } \\
\hline No & 52 & 66.7 & 67 & 73.6 & 0.323 \\
\hline Yes & 26 & 33.3 & 24 & 26.4 & \\
\hline \multicolumn{6}{|c|}{ Possible cause for urticaria } \\
\hline No & 44 & 56.4 & 75 & 82.4 & $p<0.001$ \\
\hline Yes & 34 & 43.6 & 16 & 17.6 & \\
\hline \multicolumn{6}{|c|}{ Conversion to chronic urticaria } \\
\hline No & 68 & 87.2 & 88 & 96.7 & 0.021 \\
\hline
\end{tabular}


may care the urticaria patients with confident information. All these reasons can be shown as an explanation for the low urticaria prevalence in our university hospital population.

Many of the urticaria patients prefer to turn to an emergency department when they seek treatment for their acute attacks. This is because of the fact that the emergency departments are the only places where they can get treatment at night and other extraordinary times. Furthermore the difficulty of getting an appointment waiting for a long time at allergy-immunology or dermatology clinics make emergency department more preferential. For all these reasons, emergency physicians need expert opinion about urticaria management and treatment. When the literature has been searched from PubMed and Turkish database 'Ulakbim', with 'urticaria' and 'allergic reaction' keywords, an article describing the urticaria patients in Turkish population and emergency departments cannot be found.

Gaig et al. ${ }^{[4]}$ conducted an epidemiological populationbased study among adults. After calculating a sample size from a population of 105.603 individuals for maximum variability, they randomly chose 5.003 individuals who were questioned by phone calls for depicting demographic distribution and prevalence of chronic urticaria. The average age of onset was 40 years. They found a $0.6 \%$ (95\% Cl: 0.4-0.8) prevalence of chronic urticaria. The prevalence of chronic urticaria was significantly higher in women $(0.48 \%)$ than in man $(0.12 \%)$ with an $\mathrm{OR}=3.82(95 \% \mathrm{Cl} 1.56-9.37)$. Acute urticaria episodes in the population were $18.72 \%(95 \% \mathrm{Cl}$ : 22.3-15.19) and acute urticaria prevalence was also higher in women than in man with an $\mathrm{OR}=1.64(95 \% \mathrm{Cl} 1.4-1.9)$. Humpreys and Hunter ${ }^{[5]}$ collected the data of 390 consecutive patients between 8 and 80 ages, seen in dermatology clinics between 1977-1979 and 1989-1993 with two separate cohorts. They found that 230 (61\%) of the patients were women and the median age at the onset of symptoms was 40 years. 61 patients (16\%) was diagnosed as acute urticaria. Simonart et al. ${ }^{[1]}$ retrospectively analyzed the records of 676 patients admitted to emergency department for acute urticaria in order to know the particularities and the main etiologies. They found that the mean age was 28 and females were affected more than males. Nettis et al. ${ }^{[6]}$ carried out a prospective study on 562 consecutive patients who had been referred to an allergy-immunology clinic with urticaria and/or angioedema between 1996 and 1999 and analyzed the prevalence of various forms of urticaria according to an etiological and clinical classification. The mean age was $35 \pm 16$ years and $384(68 \%)$ were female. Many of the patients were diagnosed as chronic urticaria (55\%) while only $7.6 \%$ of them diagnosed as acute urticaria.

The four study results aforementioned above stated that urticaria was seen more in women in population-based stud- ies, dermatology and allergy immunology clinics and emergency departments. We searched 3813 urticaria patients retrospectively and found the similar gender and age rates with all these studies except the study reporting the mean age as 28 , conducted by Simonart et al. ${ }^{[1]}$

Acute and chronic urticaria separation is done due to the duration of the symptoms. Symptoms lasting more than 6 weeks are assessed as chronic urticaria. Chronic urticaria is seen in only a subgroup of patients and progresses in a long course with relapsing acute attacks. Despite the higher prevalence of acute urticaria in population-based studies, chronic urticaria prevalence is found to be higher in dermatology and allergy-immunology clinics ${ }^{[6]}$ This data offer that acute urticaria patients commonly admit to emergency department and primary care units. Chronic urticaria patients can manage their acute attacks at home without coming to a clinic, using their experience from the previous attacks.

The etiologic triggering factors for acute urticaria or personal history of an allergic disease were searched in various studies. A study conducted by Zuberbier et al. ${ }^{[7]}$ in 1996 showed that $50.2 \%$ of acute urticaria patients had an allergic asthma or atopic dermatitis in the past medical history. In their study Humpreys and Hunter reported that, 103 patients (26\%) from a total of 390 suffered from an atopic or asthmatic disease and the etiologic factors could not be shown in 217 patients $(56 \%)^{[5]}$ Nettis et al. reported family atopy history in 197 patients (35\%) from a total of 562 patients, in their prospective study of urticaria and/or angioedema patients. Due to the patient's anamnesis, 105 patients $(19 \%)$ reported a history of reactions to drugs, 66 patients (12\%) had a history of food reactions. In addition, urticaria reactions in $8 \%$ of the patients resulted from IgE-mediated type I allergic reactions due to drugs, foods, inhalants and Hymenoptera while $6 \%$ of the cases were caused urticaria by non-immunological pathways triggered by drugs, foods or additives. ${ }^{[6]}$

In the present study, 169 patients in control group and revisit group were detected and found out that 42 patients (24.9\%) had previous allergy history and 50 patients (29.6\%) had previous urticaria history. These results were similar with the previous studies mentioned above. However past medical history of urticaria or allergy did not significantly affect the revisits.

It is well-established that food allergies are common causes of acute urticaria in children however this is not clear for adults ${ }^{[8]}$ Simons et al ${ }^{[9]}$ found a common association with food ingestion and urticaria episodes in children. Legrain et al. ${ }^{[10]}$ reported food, mainly cow's milk, to be relevant for acute urticaria in 10 of 12 infants. However in adults, especially in chronic urticaria, the pseudoallergens are more common than the direct allergic role of the food. ${ }^{[11]}$ For example 
Aoki et al. ${ }^{[12]}$ searched 50 adult patients in a prospective epidemiologic study and none of the patients had a food allergy, whereas $62 \%$ of patients had an upper respiratory tract infection. Zuberbier et al. ${ }^{[13]}$ evaluated the possible benefits of a stringently controlled pseudoallergen-free diet in a prospective study and in $73 \%$ of patients; symptoms ceased or were greatly reduced within 2 weeks on diet. These results were confirmed by Pigatto and Valsecchi ${ }^{[14]}$ who investigated a group of 202 patients with chronic urticaria using the same diet. In this study 126 (62.4\%) patients improved on diet.In light of the foregoing, it can be foreseen that restricting pseudoallergens from the diet can improve the symptoms at various degrees in chronic urticaria patients.

In the present study, the presence of a possible cause for the urticaria symptoms was found to be statistically significant in revisit group. The high levels in this group may be related to the food and/or additives. The higher chronic urticaria conversion in the revisit group may also support this claim. Since all patients did not visit the dermatology clinic after the emergency department visits, the data on patients at the hospital database were not sufficient. Therefore, we could not be able to confirm the certain etiologic role of food or other factors on urticaria. The data of a prospective designed study for investigating the etiologic agents will give more useful and confidential information.

The patients triaged as 'emergent' according to triple triage system we used in our emergency department can be thought to have serious systemic urticaria. Stewart and Evan, ${ }^{[15]}$ in a retrospective study conducted in an emergency department with 55.000 annual visits, found $9(0.16 \%)$ severe anaphylaxis reaction from a total of $24(0.4 \%)$ generalized allergic reactions. Bellou et al. ${ }^{[16]}$ reported $1 \%$ generalized reaction incidence and $0.037 \%$ anaphylactic shock incidence in their retrospective study. In the present study, patient ratio triaged as 'emergent' was found $1.4 \%$. This high rate can be explained by the general classification of patients rather than urticaria classification. However, despite this classification difference, the high hospitalized patient ratio as $1.2 \%$, can predict that our patient population cover more serious patient than other studies. Since our hospital is a reference center in a region with 2-3 million people, we could see more serious patients than other hospitals, as well as patients may prefer us at their serious attacks.

Bellou et al. ${ }^{[16]}$ observed that nearly half the ED visits took place in summer which suggested that there was a seasonal factor. This could be due to the high frequency of allergies to hymenoptera registered in summer, which is consistent with the life cycle of this type of insect. In the present study, there was not any difference between the seasons of the year, between the patient demographics and revisits. Except the study mentioned above, other papers remarked seasonal difference as an unforeseen circumstance for urticaria, so our data was compatible with general literature. Unascertained possible causes of urticaria also support this information.

Acute urticaria treatment with combined $\mathrm{H} 1$ and $\mathrm{H} 2$ blockade has been shown to have advantages over $\mathrm{H} 1$ blockade alone. Bleehen et al. ${ }^{[17]}$ used chlorpheniramine+cimetidine or chlorpheniramine+placebo in the treatment of chronic idiopathic urticaria, in a multi-centre randomized double-blind study for 120 chronic idiopathic urticaria patients. There was a statistically significant difference between the average response in the two treatment groups in favor of chlorpheniramine plus cimetidine after 4 and 8 weeks' treatment. In a randomized, double-blind, placebo-controlled trial, Lin et al. ${ }^{[18]}$ treated 91 adult patients with acute allergic syndromes with either $50 \mathrm{mg}$ of diphenhydramine and saline solution (control group) or with $50 \mathrm{mg}$ of diphenhydramine and $50 \mathrm{mg}$ of ranitidine (active group). Both groups had similar proportions of urticaria at baseline. There were significantly more patients without urticaria in 2 hours among the patients in the active group compared with those in the control group. In the present study, there was not any significant difference between the patients in revisit or control group, who received $\mathrm{H} 1$ antagonist alone or with a $\mathrm{H} 2$ antagonist in the prescription. Even though we could not be able to confirm the advantage of receiving $\mathrm{H} 1$ and $\mathrm{H} 2$ receptor blockers together, combined therapy is $2 \mathrm{C}$ level evidence according to SIGN (Scottish Intercollegiate Guidelines Network). ${ }^{[19]}$ A prospective randomized double-blind placebo controlled study will give useful information about this treatment options.

\section{Limitations}

One of the limitations for the present study is because of the retrospective design: we were not able to check the patients if they used their prescribed medications regularly as we taught them or if they used any other medicines. The second limitation is that: if the patient went to another medical center instead of our clinic for ongoing urticaria symptoms within the 5 days, than we did not have them in our revisit group. Therefore our revisit group could be higher than detected.

\section{Conclusion}

Before all else, this study has pointed out the scores of urticaria patients entering to emergency departments. Besides, these patients may have life-threatening problems or sometimes may need hospitalization. This information can be used for modifying emergency clinics curriculum and can contribute to the standardization of the urticaria management and follow up. Since there is quite similarity between our results and the international literature, this study might blaze a trail for new prospective studies about urticaria. When the literature searched, standard diagnostic tests and treatment mo- 
dalities cannot be found especially for emergency department patients. Future prospective studies can be conducted for urticaria management in light of our results.

\section{Conflict of Interest}

The authors declare that there is no potential conflicts of interest.

\section{References}

1. Simonart T, Askenasi R, Lheureux P. Particularities of urticaria seen in the emergency department. Eur J Emerg Med 1994;1:80-2.

2. Dibbern DA Jr. Urticaria: selected highlights and recent advances. Med Clin North Am 2006;90:187-209.

3. Kaplan AP. Urticaria and angioedema. In: Adkinson NF, Yunginger JW, Busse WW editors. Middleton's allergy: principles and practice. Vol. 2., 6th ed., Philadelphia: Mosby; 2003. p. 1537-58.

4. Gaig P, Olona M, Muñoz Lejarazu D, Caballero MT, Domínguez FJ, Echechipia S, et al. Epidemiology of urticaria in Spain. J Investig Allergol Clin Immunol 2004;14:214-20.

5. Humphreys F, Hunter JA. The characteristics of urticaria in 390 patients. Br J Dermatol 1998;138:635-8.

6. Nettis E, Pannofino A, D'Aprile C, Ferrannini A, Tursi A. Clinical and aetiological aspects in urticaria and angio-oedema. $\mathrm{Br} \mathrm{J}$ Dermatol 2003;148:501-6.

7. Zuberbier T, Iffländer J, Semmler C, Henz BM. Acute urticaria: clinical aspects and therapeutic responsiveness. Acta Derm Venereol 1996;76:295-7.

8. Zuberbier T. Urticaria. Allergy 2003;58:1224-34.
9. Simons FE. Prevention of acute urticaria in young children with atopic dermatitis. J Allergy Clin Immunol 2001;107:7036.

10. Legrain V, Taïeb A, Sage T, Maleville J. Urticaria in infants: a study of forty patients. Pediatr Dermatol 1990;7:101-7.

11. Khalaf AT, Li W, Jinquan T. Current advances in the management of urticaria. Arch Immunol Ther Exp (Warsz) 2008;56:103-14.

12. Aoki T, Kojima M, Horiko T. Acute urticaria: history and natural course of 50 cases. J Dermatol 1994;21:73-7.

13. Zuberbier T, Chantraine-Hess S, Hartmann K, Czarnetzki BM. Pseudoallergen-free diet in the treatment of chronic urticaria. A prospective study. Acta Derm Venereol 1995;75:484-7.

14. Pigatto PD, Valsecchi RH. Chronic urticaria: a mystery. Allergy 2000;55:306-8.

15. Stewart AG, Ewan PW. The incidence, aetiology and management of anaphylaxis presenting to an accident and emergency department. QJM 1996;89:859-64.

16. Bellou A, Manel J, Samman-Kaakaji $H$, de Korwin JD, Moneret-Vautrin DA, Bollaert PE, et al. Spectrum of acute allergic diseases in an emergency department: an evaluation of one years' experience. Emerg Med (Fremantle) 2003;15:341-7.

17. Bleehen SS, Thomas SE, Greaves MW, Newton J, Kennedy $\mathrm{CT}$, Hindley F, et al. Cimetidine and chlorpheniramine in the treatment of chronic idiopathic urticaria: a multi-centre randomized double-blind study. Br J Dermatol 1987;117:81-8.

18. Lin RY, Curry A, Pesola GR, Knight RJ, Lee HS, Bakalchuk L, et al. Improved outcomes in patients with acute allergic syndromes who are treated with combined $\mathrm{H} 1$ and $\mathrm{H} 2$ antagonists. Ann Emerg Med 2000;36:462-8.

19. Zuberbier T, Bindslev-Jensen C, Canonica W, Grattan CE, Greaves MW, Henz BM, et al. EAACI/GA2LEN/EDF guideline: management of urticaria. Allergy 2006;61:321-31. 